\title{
電気化学
}

[ 特 集]

\section{次号予 告}

電気化学 / 光電気化学プロセスを利用した二酸化炭素還元

1. 金属錯体光触媒を用いた二酸化炭素還元と複合系への 展開 $\cdots \cdots \cdots \cdots \cdots \cdots$ 熊谷 啓，鎌田龍太郎，石谷 治

2. 粉末半導体光触媒を用いる人工光合成型二酸化炭素還元 $\ldots \ldots \ldots \ldots \ldots \ldots$ 吉野隼矢，岩瀬顕秀，工藤昭彦

3. 酸化物光触媒のバンドエンジニアリングによる $\mathrm{H}_{2} \mathrm{O}$ を 電子源とする $\mathrm{CO}_{2}$ の光還元の長波長駆動化

吉川聡一, 寺村謙太郎, 朝倉博行, 細川三郎, 田中庸裕

4. 無機材料をベースとした可視光駆動型選択的 $\mathrm{CO}_{2}$ 還元 システム

…宮内雅浩, Yin Ge, 庄司州作，山口 晃，阿部英樹

5. ダイヤモンド半導体を用いた二酸化炭素の光電気化学 還元……中林志達, 近藤剛史, 藤嶋 昭, 寺島千晶

6. ダイヤモンド電極を用いた二酸化炭素の電解還元 ……………夏井敬介, 冨㠃真衣, 栄長泰明

7. 固体高分子形セルを用いる二酸化炭素の電気化学的還元 ................................... 梅田 実

\section{[測定法講座]}

電気化学反応のその場測定法

1. 電気化学反応のその場分光法（仮題）

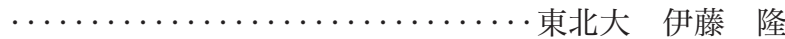

2. 電気化学反応のその場観察技術（仮題）

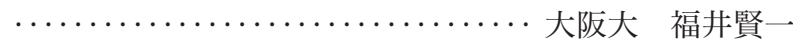
ほか

\section{複写をされる方へ}

本会は下記協会に複写に関する権利委託をしていますので，本誌に揭 載された著作物を複写したい方は，同協会より許諾を受けて複写して下 さい，但し(社)日本複写権センター（同協会により権利を再委託）と包括 複写許諾契約を締結させている企業の社員による社内利用目的の複写は その必要はありません。(社外頒布用の複写は許諾が必要です.)

権利委託先：(一般社団法人) 学術著作権協会

厂 107-0052 東京都港区赤坂 9-6-41 乃木坂ビル 3F

(Tel 03-3475-5618, FAX 03-3475-5619, E-mail : info@jaacc.jp)

なお，著作物の転載・翻訳のような，複写以外の許諾は，学術著作権 協会では扱っていませんので, 直接発行団体へご連絡ください.

また，アメリカ合衆国に扔いて本書を複写したい場合は，次の団体に 連絡して下さい.

Copyright Clearance Center, Inc.

222 Rosewood Drive, Danvers, MA 01923, USA

Phone : 1-978-750-8400, Fax : 1-978-750-4744

\section{Notice for photocopying}

If you wish to photocopy any work of this publication, you have to get permission from the following organization to which licensing of copyright clearance is delegated by the copyright owner.

All users except those in USA

Japan Academic Association for Copyright Clearance lnc. (JAACC)

6-41 Akasaka 9-chome, Minato-ku, Tokyo 107-0052, Japan

Phone : 81-3-3475-5618,.Fax : 81-3-3475-5619,E-mail : info@jaacc.jp

User in USA

Copyright Clearance Center, Inc.

222 Rosewood Drive, Danvers, MA 01923, USA

Phone : 1-978-750-8400, Fax : 1-978-750-4744
論文投稿規程・手引などの掲載巻号

入会案内 ; 85 (2017) No. 1

会員異動届；85（2017） No. l

投稿規程 ; 86 (2018) Spring

英文投稿規程 ; 85（2017） No. 1

投稿手引； 86 (2018) Spring

英文投稿手引；85（2017） No. 8

\section{電気化学 (Denki Kagaku)}

第 86 巻 冬号 第 4 種郵便物「学術刊行物」 編集兼発行人

公益社団法人 電気化学会

印刷所 $=162-0808$ 東京都新宿区天神町 78

発行所 干 101-0065 東京都千代田区西神田 3 丁目 1 番 6 号

\section{日本弘道館ビル $7 \mathrm{~F}$}

公益社団法人

電 気 化 学 会

The Electrochemical Society of Japan TEL 03 （3234）4213, FAX 03 (3234） 3599 http://www.electrochem.jp 